\title{
EFFECT OF ATROMID AND ITS COMPONENTS ON URIC ACID EXCRETION AND ON GOUT
}

\author{
BY \\ G. TREVAKS AND R. R. H. LOVELL \\ University of Melbourne Department of Medicine, The Royal Melbourne Hospital, Victoria, Australia
}

In the early studies on atromid, which is ethyl p-chlorophenoxyisobutyric acid (clofibrate or C.P.I.B.) with androsterone, Thorp (1962) reported that, in monkeys, this preparation increased uric acid excretion in addition to lowering plasma lipids. Also Oliver (1962) reported that atromid lowered serum uric acid levels in patients with ischaemic heart disease. We therefore investigated its possible usefulness as a uricosuric agent.

The acute effects of atromid and its components on urinary excretion of uric acid in man were studied first. C.P.I.B. alone was found to have at least as potent an effect on uric acid excretion as atromid. Experiments were then done to see if acetylsalicylic acid antagonized the effect of C.P.I.B., as it does the effects of probenecid (Yü and Gutman, 1959). Finally, the effect of long term administration of atromid on the serum uric acid levels of patients with gout is reported.

\section{Material and Methods}

(1) Acute effect of atromid and its components on the renal excretion of uric acid.-Seven non-gouty patients with normal renal function were studied in hospital (Table I). Blood was taken and 24-hr collections of urine were made on three consecutive days from 8 a.m. No drugs were given on the first or third day. On the second day one of the following was given: atromid 35 $\mathrm{mg} . / \mathrm{kg}$. in three divided doses, or C.P.I.B. $35 \mathrm{mg} . / \mathrm{kg}$. in

$$
\text { TABLE I }
$$

PATIENTS IN THE FIRST STUDY

\begin{tabular}{c|c|c|l}
\hline Patient No. & Age (yrs) & Sex & \multicolumn{1}{|c}{ Diagnosis } \\
\cline { 2 - 3 } & 38 & M & Ulcerative colitis \\
2 & 32 & M & Peptic ulcer \\
3 & 53 & M & Peptic ulcer \\
4 & 29 & M & Chronic bronchitis \\
5 & 36 & M & Neurofibroma of the lung \\
6 & 49 & Th & Thyroiditis \\
7 & 42 & M & Haemorrhoids \\
\hline
\end{tabular}

three divided doses, or androsterone $50 \mathrm{mg}$. in a single oral dose at 8 a.m.

Uric acid and creatinine were measured in urine and blood samples.

(2) Effect of acetylsalicylic acid on the acute uricosuric action of C.P.I.B.-Five non-gouty subjects with normal renal function were studied in hospital (Table II). Urine passed during the same 8-hr period each day was collected on three consecutive days. At the beginning of each collection period, four patients were each given no drug on the first day, C.P.I.B. 2 g. alone on the second day, and C.P.I.B. $2 \mathrm{~g}$. with aspirin $0.6 \mathrm{~g}$. on the third day. The fifth patient received C.P.I.B. with aspirin on the second day and C.P.I.B. alone on the third day.

TABLE II

PATIENTS IN THE SECOND STUDY

\begin{tabular}{c|c|c|l}
\hline Patient No. & Age (yrs) & Sex & \multicolumn{1}{|c}{ Diagnosis } \\
\hline 1 & 43 & $\mathbf{M}$ & Anxiety \\
2 & 32 & M & Epilepsy \\
3 & 41 & Chronic alcoholism \\
4 & 35 & M & Asthma \\
5 & 56 & M & Carcinoma of the lung \\
\hline
\end{tabular}

Uric acid and creatinine were measured in urine and blood samples.

(3) Effect of long-term administration of atromid on serum uric acid levels in gout.-Six male patients with typical gout were studied, some details about them and their treatment being shown in Table III (opposite). All received atromid $30 \mathrm{mg}$. $/ \mathrm{kg}$./day in divided doses, the only other drug permitted was colchicine. Blood samples were taken at about 9 a.m. from these patients on several occasions before and during treatment for measurement of uric acid, and, periodically, for measurement of blood urea and serum glutamic oxalacetic transaminase (S.G.O.T.).

In all the studies serum and urinary uric acid were measured by the enzymatic spectrophotometric method of Liddle, Seegmiller, and Laster (1959). Serum and urinary creatinine levels were measured by a modification 
TABLE III

PATIENTS WITH GOUT WHO RECEIVED LONG-TERM ATROMID

\begin{tabular}{|c|c|c|c|c|}
\hline Patient No. & Age (yrs) & Tophi & $\begin{array}{c}\text { Dosage of Atromid } \\
\text { (g./day) }\end{array}$ & $\begin{array}{c}\text { Duration of Treatment } \\
\text { (wks) }\end{array}$ \\
\hline $\begin{array}{l}1 \\
2 \\
3 \\
4 \\
5 \\
6\end{array}$ & $\begin{array}{l}41 \\
52 \\
43 \\
41 \\
35 \\
70\end{array}$ & $\begin{array}{l}- \\
+ \\
+ \\
+ \\
+ \\
-\end{array}$ & $\begin{array}{c}2 \\
1 \cdot 5 \\
1 \cdot 5 \\
2 \\
2 \\
2 \cdot 5\end{array}$ & $\begin{array}{r}24 \\
20 \\
28 \\
6 \\
16 \\
11\end{array}$ \\
\hline
\end{tabular}

of the method of Hare (1950) which is based on the Jaffe reaction. Blood urea was measured by a diacetylmonoxine reaction using an autoanalyser. The serum glutamic oxalacetic transaminase was measured by a colorimetric determination using "Sigma" reagents and kit. All subjects studied in hospital were taking the normal hospital diet and the gouty out-patients followed their usual diets.

\section{Results}

(1) Acute effect of atromid and its components on the renal excretion of uric acid.-The amount of urinary uric acid excreted and the ratio of uric acid clearance to creatinine clearance are shown in Table IV. There was no significant variation in the serum levels of uric acid or creatinine on the days of this experiment.

When six patients were given atromid, four showed increases in urinary uric acid excretion of from 4 to 171 per cent. on the test compared with control days. In the other two patients, the urinary uric acid excretion fell 11 and 15 per cent respectively on test compared to control days.

When the same six patients were given C.P.I.B. ester, all showed some increase of urinary uric acid excretion on test compared with control days, this increase ranging from 24 to 87 per cent.
Three patients were studied with androsterone. In two, excretion of uric acid was less on the day on which androsterone was given than on both control days and in one patient it was less than on one control day.

The uric acid/creatinine clearance ratios showed no consistent pattern following atromid or androsterone. In the experiment using C.P.I.B. ester, the ratio rose on the day the drug was given compared to control days in four of the five patients in whom the estimation could be performed.

(2) Effect of acetyl salicylic acid on the acute uricosuric action of C.P.I.B.-Table V (overleaf) shows the urinary uric acid levels and uric acid/creatinine clearance ratios. There was no significant variation in serum levels of uric acid or creatinine in any of the patients throughout the three days of study. In all patients the uric acid excretion following C.P.I.B. alone was greater than that on the day on which no treatment was given. The rises were mostly large and in two patients the excretion was more than doubled. Except in Patient 4, on the days on which C.P.I.B. plus aspirin was given, the uric acid excretion was less than when C.P.I.B. alone was given. In two patients it was less than on the day

TABLE IV

EFFECT OF ATROMID, C.P.I.B. ESTER, AND ANDROSTERONE ON URINARY URIC ACID (UUA) EXCRETION AND ON THE URIC ACID/CREATININE CLEARANCE RATIO (Cua/Ccr)

\begin{tabular}{|c|c|c|c|c|c|c|c|c|c|c|c|c|c|c|c|c|c|c|}
\hline \multirow{2}{*}{\multicolumn{2}{|c|}{ Patient No. }} & \multirow{2}{*}{$\cdots$} & \multirow{2}{*}{$\cdots$} & \multirow{2}{*}{$\cdots$} & \multicolumn{2}{|c|}{1} & \multicolumn{2}{|c|}{2} & \multicolumn{2}{|c|}{3} & \multicolumn{2}{|c|}{4} & \multicolumn{2}{|c|}{5} & \multicolumn{2}{|c|}{6} & \multicolumn{2}{|c|}{7} \\
\hline & & & & & $\left|\begin{array}{c}\text { Uua } \\
\text { (mg./ } \\
24 \mathrm{hrs})\end{array}\right|$ & $\underset{\mathrm{Ccr}}{\mathrm{Cua} /}$ & $\left|\begin{array}{c}\text { Uua } \\
\text { (mg./ } \\
24 \mathrm{hrs} \text { ) }\end{array}\right|$ & $\underset{\mathrm{Ccr}}{\mathrm{Cua} /}$ & $\begin{array}{c}\text { Uua } \\
\text { (mg./ } \\
24 \mathrm{hrs})\end{array}$ & $\underset{\text { Ccr }}{\text { Cua/ }}$ & $\begin{array}{c}\text { Uua } \\
\text { (mg./ } \\
24 \mathrm{hrs} \text { ) }\end{array}$ & $\begin{array}{c}\text { Cua/ } \\
\text { Ccr }\end{array}$ & $\begin{array}{c}\text { Uua } \\
\text { (mg./ } \\
24 \text { hrs) }\end{array}$ & $\begin{array}{c}\text { Cua/ } \\
\text { Ccr }\end{array}$ & $\begin{array}{c}\text { Uua } \\
\text { (mg./ } \\
24 \mathrm{hrs})\end{array}$ & $\underset{\text { Ccr }}{\text { Cua/ }}$ & $\begin{array}{c}\text { Uua } \\
\text { (mg./ } \\
24 \text { hrs) }\end{array}$ & $\underset{\mathrm{Ccr}}{\mathrm{Cua} /}$ \\
\hline \multirow{3}{*}{ Drug } & Atromid & \multicolumn{2}{|c|}{$\begin{array}{l}\text { Day Before } \\
\text { Day of Dose } \\
\text { Day After }\end{array}$} & $\begin{array}{l}\cdots \\
\cdots\end{array}$ & $\begin{array}{r}533 \\
1,043 \\
449\end{array}$ & $\begin{array}{l}0 \cdot 16 \\
0 \cdot 12 \\
0 \cdot 09\end{array}$ & $\begin{array}{l}391 \\
340 \\
559\end{array}$ & $\begin{array}{l}0.09 \\
0.07 \\
0.13\end{array}$ & $\begin{array}{l}289 \\
334 \\
316\end{array}$ & $\begin{array}{l}0.09 \\
0.09 \\
0.09\end{array}$ & $\begin{array}{l}211 \\
573 \\
504\end{array}$ & $\begin{array}{l}0 \cdot 03 \\
0 \cdot 10 \\
0 \cdot 09\end{array}$ & $\begin{array}{l}531 \\
473 \\
383\end{array}$ & $\begin{array}{l}0.05 \\
0.06 \\
0.06\end{array}$ & $\begin{array}{l}432 \\
450 \\
270\end{array}$ & $\begin{array}{l}0 \cdot 20 \\
0 \cdot 14 \\
0 \cdot 30\end{array}$ & & \\
\hline & C.P.I.B. & \multicolumn{2}{|c|}{$\begin{array}{l}\text { Day Before } \\
\text { Day of Dose } \\
\text { Day After }\end{array}$} & $\begin{array}{l}\ldots \\
\cdots \\
\cdots\end{array}$ & $\begin{array}{l}556 \\
780 \\
593\end{array}$ & $\begin{array}{l}0.06 \\
0.08 \\
0.08\end{array}$ & $\begin{array}{l}558 \\
689 \\
488\end{array}$ & $\begin{array}{l}0 \cdot 15 \\
0 \cdot 12 \\
0.07\end{array}$ & $\begin{array}{l}291 \\
445 \\
207\end{array}$ & $\begin{array}{l}0.06 \\
0.13 \\
0.06\end{array}$ & $\begin{array}{l}419 \\
786 \\
616\end{array}$ & $\begin{array}{c}0 \cdot 16 \\
-\end{array}$ & $\begin{array}{l}520 \\
834 \\
531\end{array}$ & $\begin{array}{l}0.04 \\
0.09 \\
0.05\end{array}$ & $\begin{array}{l}355 \\
611 \\
456\end{array}$ & $\begin{array}{l}0 \cdot 13 \\
0 \cdot 25 \\
0 \cdot 13\end{array}$ & & \\
\hline & $\begin{array}{l}\text { Andro- } \\
\text { sterone }\end{array}$ & \multicolumn{2}{|c|}{$\begin{array}{l}\text { Day Before } \\
\text { Day of Dose } \\
\text { Day After }\end{array}$} & $\begin{array}{l}\ldots \\
\ldots\end{array}$ & & & & & & & & & $\begin{array}{l}870 \\
516 \\
520\end{array}$ & $\begin{array}{l}0.05 \\
0.04 \\
0.04\end{array}$ & $\begin{array}{l}460 \\
363 \\
432\end{array}$ & $\begin{array}{l}0 \cdot 13 \\
0 \cdot 12 \\
0 \cdot 20\end{array}$ & $\begin{array}{l}410 \\
580 \\
600\end{array}$ & $\begin{array}{l}0.08 \\
0.08 \\
0.09\end{array}$ \\
\hline
\end{tabular}


TABLE $\mathrm{V}$

EFFECT OF CPIB ESTER ALONE AND IN COMBINATION WITH ASPIRIN 0.6 g. ON URINARY URIC ACID EXCRETION (UUa) AND ON THE URIC ACID/CREATININE CLEARANCE RATIO (CUa/Ccr)

\begin{tabular}{|c|c|c|c|c|c|c|c|c|c|c|c|c|c|c|c|}
\hline Patient No. .. & & 1 & & & 2 & & & 3 & & & 4 & & & 5 & \\
\hline Day No. & 1 & 2 & 3 & 1 & 2 & 3 & 1 & 2 & 3 & 1 & 2 & 3 & 1 & 2 & 3 \\
\hline Treatment & $\begin{array}{l}\text { No } \\
\text { Drug }\end{array}$ & CPIB & $\begin{array}{c}\text { CPIB } \\
\text { and } \\
\text { Aspirin }\end{array}$ & $\begin{array}{l}\text { No } \\
\text { Drug }\end{array}$ & CPIB & $\begin{array}{c}\text { CPIB } \\
\text { and } \\
\text { Aspirin }\end{array}$ & $\begin{array}{l}\text { No } \\
\text { Drug }\end{array}$ & CPIB & $\begin{array}{c}\text { CPIB } \\
\text { and } \\
\text { Aspirin }\end{array}$ & $\begin{array}{l}\text { No } \\
\text { Drug }\end{array}$ & CPIB & $\begin{array}{c}\text { CPIB } \\
\text { and } \\
\text { Aspirin }\end{array}$ & $\begin{array}{c}\text { No } \\
\text { Drug }\end{array}$ & $\begin{array}{c}\text { CPIB } \\
\text { and } \\
\text { Aspirin }\end{array}$ & CPIB \\
\hline $\begin{array}{l}\text { Uua } \\
\text { (mg./8 hrs) }\end{array}$ & 150 & 245 & 176 & 218 & 457 & 164 & 139 & 261 & 114 & 212 & 227 & 262 & 136 & 183 & 347 \\
\hline $\mathrm{Cua} / \mathrm{Ccr}$ & 0.07 & 0.08 & 0.09 & 0.07 & 0.01 & 0.06 & $0 \cdot 10$ & $0 \cdot 13$ & $0 \cdot 13$ & $0 \cdot 12$ & $0 \cdot 13$ & $0 \cdot 14$ & 0.05 & 0.06 & 0.09 \\
\hline
\end{tabular}

when no drug at all was given. As in the previous experiment, changes in the urinary creatinine excretion tended to follow changes in the urinary uric acid excretion. There were thus only small changes in the uric acid/creatinine clearance ratios.

(3) Effect of long-term administration of atromid on serum uric acid levels in gout.-The results are shown in the Figure. In some patients there was a slight initial drop in the serum uric acid levels after treatment was started, but this drop was not maintained.

The patients experienced no change in the symptoms due to gout. One patient (Case 4) complained of impotence 6 weeks after treatment with atromid commenced; for this reason, the drug was stopped, and the impotence disappeared.

The S.G.O.T. rose to 50 units in one patient (Case 1) 20 weeks after treatment with atromid was started and was still at the same level 4 weeks later when treatment was stopped. His S.G.O.T. subsequently returned to normal. Transient elevation of the S.G.O.T. during atromid administration was reported by Oliver (1962).

\section{Discussion}

These results show that a single dose of C.P.I.B. consistently causes an increase in excretion of uric acid. Although C.P.I.B. with androsterone sometimes has a similar effect, it appears to be less consistent and the findings in the first study suggest a possible inhibitory effect of androsterone on uric acid excretion. This is not, however, established.

The demonstration that aspirin inhibits the uricosuric effect of C.P.I.B. suggests that, like probenecid and sulphinpyrazone, its action is exerted mainly on the renal tubular handling of uric acid. However, while its mode of action may be similar, atromid in the doses used did not cause the falls in serum uric acid, sustained over many months, which are produced by probenecid or sulphinpyrazone (Ogryzlo

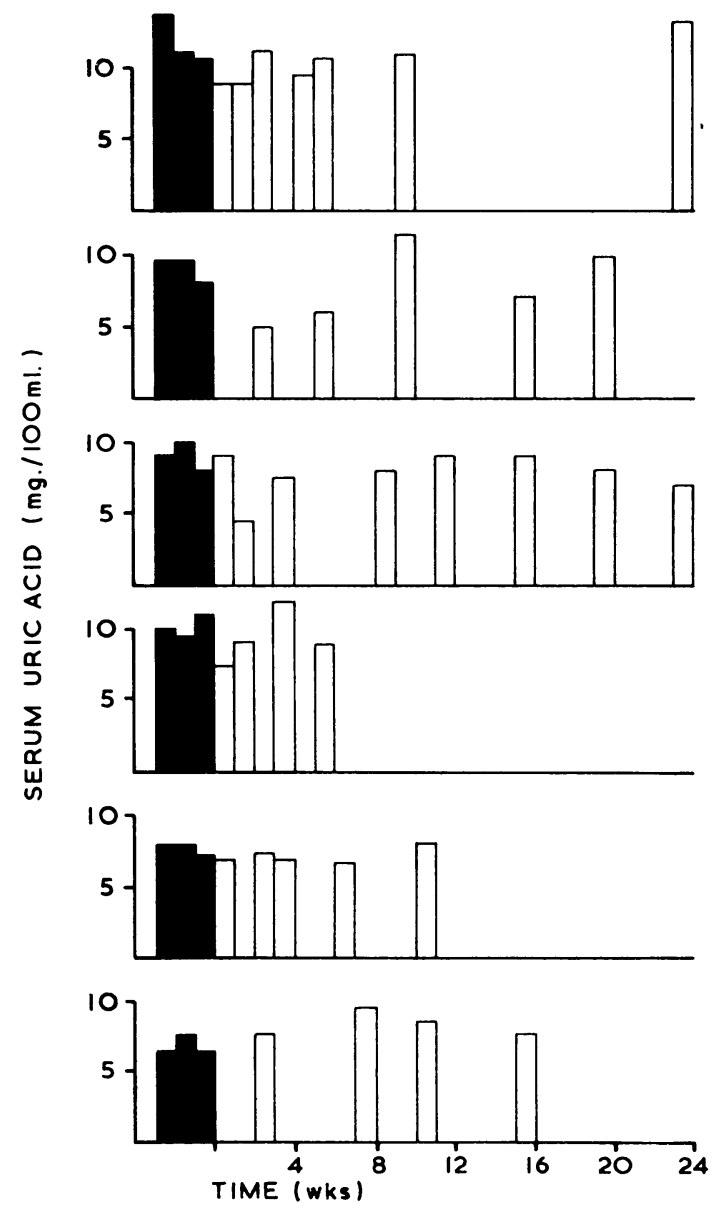

Figure.-Serum uric acid levels in six patients with gout, before black columns) and during (open columns) treatment with atromid.

and Harrison, 1959). Our failure to sustain lowered levels of serum uric acid with atromid accords with the experience of Hellman, Zumoff, Kessler, Kara, Rubin, and Rosenfeld (1963), who 
used C.P.I.B. in 23 hyperuricaemic patients. Similarly atromid and C.P.I.B. failed to lower the serum uric acid in subjects with normal uric acid levels (Howard, Alauprovic, Brusco, and Furman, 1963; Jepson and James, 1963; Green, Inman, and Thorp 1963). There is, however, a report of a mean fall in serum uric acid of $1.15 \mathrm{mg} . / 100 \mathrm{ml}$. in subjects with normal serum uric acid levels (Fasoli and Cesana, 1963).

The relatively weak and transient effect of atromid on serum uric acid levels might reflect the use of a relatively small dose and this possibility can be examined if larger doses prove to be safe. Alternatively, it is possible that the immediate effect on uric acid excretion is quickly overcome by compensatory mechanisms.

\section{Summary}

(1) The effects on uric acid excretion of single doses of C.P.I.B. with androsterone, C.P.I.B. alone, and androsterone alone were compared. C.P.I.B. consistently, and C.P.I.B. with androsterone sometimes, increased urinary uric acid excretion.

(2) The uricosuric effect of C.P.I.B. was prevented by simultaneous administration of acetylsalicylic acid.

(3) Atromid was administered to six patients with gout for periods of between 6 and 24 weeks. In no case was there a sustained fall in the serum uric acid.

We should like to thank Dr. C. W. Marsden, of Imperial Chemical Industries, Ltd., who supplied the atromid, C.P.I.B. ester, and androsterone, and Mr. V. Scott of I.C.I.A.N.Z. for his co-operation. We are also grateful to Miss Judith Hammond for technical assistance and to Dr. C. W. Baird for help with biochemical estimations.

\section{REFERENCES}

Fasoli, A., and Cesana, A. (1963). J. Atherosclerosis Res., 3, 475.

Green, K. G., Inman, W. H. W., and Thorp, J. M. (1963). Ibid., 3, 593.
Hare, R. S. (1950). Proc. Soc. exp. Biol. (N. Y.), 74, 148.

Hellman, L., Zumoff, B., Kessler, G., Kara, E., Rubin, I. L., and Rosenfeld, R. S. (1963). Ann. intern. Med., 59, 477.

Howard, R. P., Alaupovic, P., Brusco, O. J., and Furman, R. H. (1963). J. Atherosclerosis Res., 3, 482.

Jepson, E. M., and James, D. C. O. (1963). Ibid., 3, 554. Liddle, L., Seegmiller, J. E., and Laster, L. (1959). J. Lab. clin. Med., 54, 903.

Ogryzlo, M. A., and Harrison, J. (1957). Ann. rheum. Dis., 16, 425.

Oliver, M. F. (1962). Lancet, 1, 1321.

Thorp, J. M. (1962). Ibid., 1, 1323.

Yü, T. F., and Gutman, A. B. (1959). J. clin. Invest., 38, 1298.

L'effet de l'Atromid et de ses composants sur l'excrétion de l'acide urique et sur la goutte

\section{RÉSUMÉ}

1. On compara les effets sur l'excrétion de l'acide urique d'une seule dose de C.P.I.B. (chlorophenoxyisobutyrate-Lipavlon) avec androstérone, C.P.I.B. seul et androstérone seul. Le C.P.I.B. toujours, et le C.P.I.B. avec androstérone quelquefois, augmentait l'excrétion de l'acide urique.

2. L'effet uricosurique du C.P.I.B. était empéché par l'administration simultanée de l'acide acétylsalicylique.

3. Atromid fut administré pendant 6 à 24 semaines à six malades atteints de goutte. Dans aucun case on ne nota de chute soutenue de l'acide urique sanguin.

El efecto del Atromid y de sus componentes sobre la depuración del ácido úrico y sobre la gota

\section{Sumario}

1. Se compararon los efectos sobre la depuración del ácido úrico de una sola dosis de C.P.I.B. (clorofenoxiisobutirato) con androsterona, de C.P.I.B. solo y de androsterona sola. El C.P.I.B. siempre, y el C.P.I.B. con androsterona a veces aumentaba la depuración del ácido úrico.

2. El efecto uricosúrico del C.P.I.B. fué impedido por la administración simultánea de ácido acetilsalicílico.

3. El Atromid fué administrado durante 6 a 24 semanas a seis enfermos con gota. En ningún caso se notó una caida sostenida del ácido úrico en el suero. 